\title{
Penggunaan Konjungsi Koordinatif Dalam Penyususnan Teks Anekdot Siswa Kelas X Di Kota Mataram
}

\author{
Isna Dia'ul Adha', Mahsun², Johan Mahyudi ${ }^{3}$ \\ Magister Pendidikan Bahasa Indonesia, FKIP, Universitas Mataram \\ isnadiauladha@gmail.com, mahsunirn@gmail.com,johan_mahyudi@unram.ac.id
}

\begin{abstract}
This study aims to measure students' ability to produce text in Indonesian language learning. The focus of this research is to describe students' ability to write anecdotal texts by utilizing coordinate/equivalent conjunctions. Text-based learning has been implemented for a long time in Indonesia and this research was conducted to see if students' ability to produce text has increased. The population of this research is secondary education students in Mataram City and to facilitate the course of research selected 40 students as a sample provided that all students have received the same learning. This research is included in qualitative research. The results of this study showed that students' ability to produce anecdotal texts in the category was lacking. It is hoped that this research has success in helping to improve students' writing ability in producing a text.
\end{abstract}

Keywords: Producing, Anecdotal Text, Coordinate/Equivalent Conjunctions

\begin{abstract}
Abstrak. Penelitian ini bertujuan untuk mengukur kemampuan siswa dalam memproduksi teks dalam pembelajaran bahasa Indonesia. Fokus penelitian ini untuk mendeskripsikan kemampuan siswa menulis teks anekdot dengan memanfaatkan konjungsi koordinatif/setara. Pembelajaran berbasis teks telah diterapkan cukup lama di Indonesia dan penelitian ini dilakukan untuk melihat apakah kemampuan siswa memproduksi teks telah semakin meningkat. Populasi penelitian ini adalah siswa jenjang pendidikan menengah di Kota Mataram dan untuk mempermudah jalannya penelitian dipilih 40 siswa sebagai sampel dengan ketentuan semua siswa telah mendapat pembelajaran yang sama. Penelitian ini termasuk kedalam penelitian kualitatif. Hasil penelitian ini menunjukkan bahwa kemampuan siswa dalam memproduksi teks anekdot dalam kategori kurang. Diharapkan penelitian ini memiliki keberhasilan dalam membantu meningkatkan kemampuan menulis siswa dalam memproduksi sebuah teks.
\end{abstract}

Kata kunci: Memproduksi, Teks Anekdot, Konjungsi Koordinatif/Setara

\section{PENDAHULUAN}

Memproduksi teks adalah sarana penilaian diri untuk siswa. Memproduksi termasuk ke dalam kemampuan berpikir kompleks, karena melibatkan proses berpikir abstrak. Untuk mampu dalam memproduksi teks siswa harus terbiasa dalam mengumpulkan data, informasi, membaca dan mengamati suatu topik masalah.

Keterampilan memproduksi teks dapat dimulai dengan melihat kemampuan siswa dalam memproduksi teks anekdot. Kompetensi inti dalam kurikulum 2013 kelas X terdiri dari: 1) spiritual, 2) bidang sosial, 3) pengetahuan, dan 4) keterampilan. Sesuai KI keterampilan dengan menjalankan KD 3.6 Menganalisis struktur dan kebahasaan teks anekdot, serta 4.6 yaitu menciptakan kembali teks anekdot dengan memperhatikan struktur dan kebahasaan, dengan kompetensi dasar tersebut memiliki indikator; a) mampu menyusun kerangka teks anekdot dengan menentukan pokok-pokok pikiran karangan, dan b) mengembangkan kerangka teks anekdot menjadi sebuah teks anekdot dengan memperhatikan aspek kebahasaan secara tertulis.

Memproduksi teks, tidak akan lepas dari penggunaan konjungsi, berdasarkan hal tersebut secara umum penelitian ini bertujuan untuk melihat kemampuan siswa dalam memproduksi teks dan secara spesifik penelitian ini akan dikhususkan pada pembuktian secara kualitatif 
terhadap kemampuan siswa menggunakan konjungsi koordinatif dalam menyusun teks anekdot. Hasil memproduksi teks dapat memperlihatkan bagaimana siswa memanfaatkan kemampuan berpikir dalam mengisi piranti kebahasaan, jika teks yang diproduksi tepat dan optimal maka siswa telah berhasil dalam memahami teks yang telah dipelajari. Dengan diketahuinya kemampuan memproduksi siswa di wilayah kota Mataram, dapat dijadikan sebagai tolok ukur kemampuan siswa dalam pembelajaran berbasis teks.

Secara khusus penelitian ini akan difokuskan pada topik yang berhubungan dengan standar proses pembelajaran yaitu pemanfaatan siswa menggunakan konjungsi koordinatif dalam memproduksi teks anekdot.

\section{TINJAUAN PUSTAKA}

Beberapa penelitian yang merujuk terhadap kemampuan memproduksi teks sesuai kurikulum 2013 telah banyak dilakukan, adapun beberapa penelitian yang memiliki urgensi dalam penelitian ini di antaranya sebagai berikut.

Pertama, penelitian yang dilakukan oleh Pinanka (2016) penelitian yang berjudul Teks dan Konteks pada Wacana Anekdot Siswa Kelas X SMA Negeri 1 Surakarta. Kedua, penelitian oleh Simanungkalit dkk (2017) dengan judul Peningkatan Motivasi dan Keterampilan Menulis Teks Anekdot dengan Model Problem Based Learning (PBL) dan Penggunaan Media Gambar Karikatur di Kelas X MM 3 SMK Negeri 1 Gondang. Ketiga, penelitian yang dilakukan oleh Irwansyah (2018) dengan judul Analisis Kemampuan Siswa Kelas X MAN 1 Bima dalam Memproduksi Teks Anekdot Menggunakan Pendekatan Saintifik

Merujuk pada penelitian-penelitian tersebut penelitian ini berfokus kepada kemampuan siswa memanfaatkan konjungsi koordinatif/setara dalam memproduksi teks anekdot pada sekolah di Kota Mataram.

\section{LANDASAN TEORI}

Ada dua teori dasar yang patut dirumuskan terlebih dahulu dalam penelitian ini, yaitu teks anekdot dan konjungsi koordinatif. Untuk lebih jelasnya pembahasan tersebut disajikan sebagai berikut.

\section{Teks Anekdot}

Zainurrahman (2011:128) menyebutkan bahwa teks adalah seperangkat unit bahasa, baik lisan maupun tulisan, dengan ukuran tertentu, makna tertentu, serta tujuan tertentu. Teks bersifat sistematis dan memiliki struktur teratur, dengan elemen-elemen yang mana jika terjadi perubahan pada salah satu elemen maka akan berdampak sistemik.

Teks adalah sebuah hasil pikiran yang lahir dari pengalaman, hasil bacaan, tindakan, dan rasa yang dituangkan ke dalam ungkapan secara lisan, atau ditulis melalui tulisan yang dapat dibaca berdasarkan kaidah-kaidah penulisan yang tepat dan memperhatikan koheren dan kohesi. Teks juga dapat dijadikan sarana dalam memberikan ilustrasi, deskripsi, gambaran, dan informasi baik dalam bentuk lisan maupun tulisan yang dapat dibagi kedalam genre yang berbeda. Oleh karena itu dipilihlah teks anekdot, karena kemampuan dan langkah siswa tidak saja mampu menarasikan sebuah cerita tetapi juga dapat memiliki pemikiran kreatif dan kritis untuk memproduksi sebuah cerita yang berdaya imajinatif, dan kemampuan itu dapat dinilai melalui kemampuan siswa dalam memproduksi teks sastra.

Menurut khazanah Jawa Kuna sastra berasal dari bahasa sansekerta yang berarti kehidupan (Emzir dan Saifur, 2016:05). Pemilihan teks sastra berkaitan dengan apa yang secara aktual dilakukan, dimaknai, dan dikatakan oleh masyarakat dalam situasi yang nyata (Darma,2009:189). Pendapat- pendapat tersebut sejalan dengan teks sastra yang dihasilkan dari tindakan dan pikiran dalam berkehidupan. Teks anekdot termasuk ke dalam jenis teks sastra, teks anekdot sebagai objek penelitian dan sebagai acuan siswa untuk dapat memproduksi teks sesuai struktur dan unsur kebahasaan teks anekdot.

Teks anekdot memiliki tujuan sosial yang sama dengan teks cerita ulang akan tetapi, peristiwa yang ditampilkan membuat partisipan yang mengalaminya merasa jengkel atau konyol (Wiratno, 2014:12). Adapun Kosasih (2014:03) menyatakan anekdot adalah sebuah cerita yang berfungsi untuk menyampaikan sebuah cerita, 
baik fiksi maupun nonfiksi, sehingga pembaca seolah-olah menyaksikan peristiwa itu, hanya saja anekdot memiliki unsur lucu atau humor yang tidak, hanya mengundang tawa tapi ajakan merenungkan suatu kebenaran.

\section{Konjungsi Koordinatif}

Konjungsi adalah bentuk hubungan konjungtif yang merealisasikan logika yang menghubungkan kejadian, kualitas, atau ide di antara klausa dan klausa (Santosa, 2011:19). Pendapat lain menyebutkan konjungsi yang dinamakan kata sambung adalah kata tugas yang menghubungkan dua satuan bahasa yang sederajat, kata dengan kata, frasa dengan frasa atau klausa dengan klausa (Alwi dkk, 2010:395).

Konjungsi koordinatif adalah konjungsi yang menghubungkan dua buah konstituen yang kedudukannya sederajat (Chaer, 2009:82), Konjungsi koordinatif/setara terdiri atas dan, serta, atau, tetapi, contohnya:

1. Rendra dan Arya bermain perang-perangan.

2. Ayu serta Ani turut membantu membersihkan rumah.

3. Intan ingin ke kampus besok tetapi ayahnya melarang.

4. Andin bingung memilih membeli perhiasan atau tanah.

Berdasarkan contoh di atas, konjungsi koordinatif memiliki fungsi untuk menghubungkan dua kalimat atau frase yang memiliki kesetaraan. Siswa diharapkan mampu menggunakan semua konjungsi koordinatif dalam memproduksi teks anekdot. Tidak hanya penggunaan 'dan' akan tetapi penggunaan 'atau', 'serta', dan 'tetapi' dalam memproduksi teks anekdot.

\section{METODE PENELITIAN}

Penelitian ini termasuk ke dalam penelitian kualitatif menurut Sugiyono (2016). Penelitian kualitatif akan memandu peneliti untuk mengeksplorasi dan memotret situasi yang akan diteliti, secara menyeluruh, luas dan mendalam. Penelitian kualitatif dilakukan untuk memahami fenomena yang dialami subjek penelitian dengan memanfaatkan berbagai metode alamiah (Moleong,2012:06). Merujuk terhadap jenis penelitian, wujud data penelitian ini dapat berupa materi pembelajaran, penugasan siswa, dan dokumentasi.

\section{Sumber Data}

Sumber data penelitian ini adalah hasil informasi dan data yang ditemukan di sekolah yang akan menjadi objek penelitian yaitu, SMAN 1 Mataram dan SMK Muhammadiyah Mataram. Kedua sekolah tersebut melakukan daring dalam pembelajarannya. Peneliti berkesimpulan dengan kemampuan siswa dalam teknologi akan memberikan hasil yang berbeda di dalam pemanfaatan daring. SMAN 1 Mataram dan SMK Muhammadiyah dipilih sebagai sumber data dalam penelitian kemampuan siswa kelas $\mathrm{X}$ memproduksi teks anekdot di Kota Mataram.

\section{Populasi Penelitian}

Populasi adalah wilayah generalisasi yang terdiri dari objek/subjek yang memiliki kualitas dan karakteristik yang ditetapkan oleh peneliti untuk dipelajari dan kemudian ditarik kesimpulannya (Sugiyono 2016:88). Populasi penelitian ini adalah sekolah SMK Muhammadiyah Mataram. Mengingat cukup banyaknya jumlah siswa, sehingga tidak memungkinkan untuk dikumpulkan data pada semua siswa tersebut, maka ditentukan sampel yang nantinya dapat dijadikan dasar untuk membuat generalisasi.

\section{Sampel Penelitian}

Penetapan sampel penelitian juga bertujuan untuk memudahkan mengubah data kualitatif menjadi data numerik/angka, selanjutnya sekolah sampel ditetapkan jumlah siswa sebanyak 40 orang yang dipilih secara acak, dengan asumsi semua siswa kelas $\mathrm{X}$ tersebut memiliki peluang yang sama untuk menjadi siswa dan mereka semua telah dipelajarkan materi teks anekdot oleh masingmasing guru.

\section{Metode Penyediaan Data}

Berpijak pada karakteristik dan wujud data penelitian, yang berupa hasil kerja/penugasan siswa yang berupa teks anekdot yang diproduksi dengan menggunakan metode saintifik, maka metode penyediaan data yang digunakan yaitu metode simak atau metode dokumentasi. Selain itu, metode ini melalui teknik bebas libat cakap, digunakan juga untuk 
menyadap perilaku atau tindakan yang dilakukan guru dalam pembelajaran bahasa dengan tanpa keterlibatan peneliti dalam proses pembelajaran tersebut (Mahsun, 358: 2017). Teknik ini digunakan untuk menyimak atau mengamati guru yang sedang memberikan tugas dalam membelajarkan siswa memproduksi teks anekdot dalam bentuk daring.

\section{Metode Analisis Data}

Data yang sudah tersedia selanjutnya dianalisis. Data akan dianalisis secara kualitatif Langkah analisis dengan menggunakan metode dan teknik ini mengindikasikan adanya lembar deskripsi capaian belajar per-siswa penelitian, yang berisi deskripsi kemampuan yang akan dianalisis. Penelitian ini hanya akan mendeskripsikan kemampuan secara kualitatif, sehingga dapat memperlihatkan kemampuan memproduksi teks siswa yang menjadi objek penelitian. Data yang ditampilkan belum merupakan data yang diperoleh dari keseluruhan siswa. Oleh karena itu, agar data itu dapat menampilkan kondisi keseluruhan siswa yang menjadi sampel penelitian, dan karenanya dapat menggambarkan kondisi kemampuan berbahasa siswa melalui ekspresi tulis berupa teks anekdot.

\section{HASIL DAN PEMBAHASAN}

Penelitian ini dilakukan di saat pandemi pada bulan Juli 2020. Peneliti menemui guru dan mengikuti jalannya pembelajaran melalui daring, materi dan tugas berupa teks anekdot diberikan kepada siswa melalui WhatsApp dan google classroom, dan siswa mengerjakan tugasnya menggunakan handphone. Oleh karena itu pemanfaatan pembelajaran untuk memantau langkah siswa dalam memproduksi teks anekdot melalui metode saintifik tidak dapat berjalan dengan efisien. Siswa mengirimkan hasil tugas menulisnya melalui online dan hasil memproduksi siswa dalam penelitian ini dapat dilihat dari tabel berikut.

Tabel 1 Deskripsi Penggunaan Konjungsi Koordinatif dalam Penyusunan Teks Anekdot SMAN 1 Mataram

\begin{tabular}{|l|l|l|}
\hline No. & Variabel & Deskripsi \\
\hline I. & Struktur Teks \\
\hline 1. & Judul & : Kotak Pensil \\
\hline
\end{tabular}
mengisi setiap struktur berpikir teks anekdot. Gagasan-gagasan pengisi struktur orientasi, krisis, dan reaksi dirajut dengan keterkaitan pasar untuk membeli kotak pensil yang ada gambar pokemon. Setelah sampai di tempat penjual kotak pensil, ia langsung bertanya apakah ada kotak pensil bergambar pokemon. Penjual pun menunjukkan kotak pensil yang di cari Marimar. Marimar memilih kotak pensil yang ingin di beli. Setelah menemukan kotak pensil yang diinginkan, Marimar bertanya harga kotak pensil pokemon yang akan dibeli. Penjual pun memberi tahu harga kotak pensil tersebut. Marimar merenggut saat mendengar harga kotak pensil tersebut karena menurutnya harganya sangat mahal.Marimar pun menawar harga kotak pensil tersebut. Penjual mempersilahkan Marimar untuk menawar.

Marimar senang saat dipersilahkan untuk menawar. Kemudian Marimar membayar kotak pensil pokemon itu setelah selesai menawar, tapi Ia malah membayar kotak pensil pokemon itu dengan harga yang lebih mahal dari yang penjual sebutkan. Setelah membayar, Marimar pun pegi dari tempat penjual kotak pensil sambil membawa kotak pensil pokemon yang dibeli.

Penjual kotak pensil hanya bisa bingung dan garuk-garuk kepala dengan kelakuan Marimar.

\begin{tabular}{|l|l|l|}
\hline II. & \multicolumn{3}{|l|}{ Penggunaan Konjungsi } \\
\hline & a. dan & $\begin{array}{l}\text { Penjual kotak pensil hanya } \\
\text { bisa bingung dan garuk-garuk } \\
\text { kepala dengan kelakuan } \\
\text { Marimar. }\end{array}$ \\
\hline & b. atau & - \\
\hline & c. tetapi & $\begin{array}{l}\text { Marimar membayar kotak } \\
\text { pensil pokemon itu setelah } \\
\text { selesai menawar, tapi Ia } \\
\text { malah membayar kotak pensil } \\
\text { pokemon itu dengan harga } \\
\text { yang lebih mahal }\end{array}$ \\
\hline e. setelaha & $\begin{array}{l}\text { Marimar membayar kotak } \\
\text { pensil pokemon itu setelah } \\
\text { selesai menawar, tapi Ia malah } \\
\text { membayar kotak pensil } \\
\text { pokemon itu dengan harga } \\
\text { yang lebih mahal }\end{array}$ \\
\hline
\end{tabular}

Tabel 1 di atas memperlihatkan siswa telah 
gagasan satu sama lain. Gagasan-gagasan dalam teks terpayungi oleh judul teks, "Kotak Pensil". Siswa dalam memproduksi/mengonstruksi telah mempertimbangkan ciri teks sebagai sesuatu yang terkontrol, antara gagasan yang terdapat pada setiap struktur teks dengan judulnya telah diorientasikan pada gagasan yang sama.

Adapun untuk pilihan konjungsi koordinatif/setara berupa pemanfaatan konjungsi, siswa telah memanfaatkan konjungsi kesetaraan: dan, dan tetapi, masing-masing dalam kalimat:

a. Kemudian Marimar membayar kotak pensil pokemon itu setelah selesai menawar, tapi Ia malah membayar kotak pensil pokemon itu dengan harga yang lebih mahal dari yang penjual sebutkan (Kalimat kedua pada struktur berpikir: Krisis)

b. Penjual kotak pensil hanya bisa bingung dan garuk-garuk kepala dengan kelakuan Marimar (struktur berpikir Reaksi).

Penggunaan konjungsi kesetaraan (te)tapi pada kalimat di atas, dari sudut pandang muatan semantis sudah sesuai fungsi konjungsi tersebut sebagai konjungsi yang mempertentangkan makna yang terdapat pada kalimat-kalimat atau klausa sebelumnya dengan makna yang terdapat pada klausa setelah konjungsi tersebut. Meskipun pada klausa pertama kalimat majemuk setara yang mempertentangkan itu tidak secara eksplisit menyebutkan harga kontak yang lebih mahal tersebut, pada kalimat-kalimat sebelumnya. Dalam hal itu, kalimat kedelapan pengisi struktur berpikir Pengenalan:

c. Marimar merenggut saat mendengar harga kotak pensil tersebut karena menurutnya harganya sangat mahal.

Keterhubungan secara semantis klausa pertama dalam kalimat majemuk setara (a) di atas dengan kalimat-kalimat sebelumnya ditandai dengan pilihan strategi linguistik penggunaan konjungsi temporal: kemudian, yang ditempatkan pada posisi awal klausa pertama kalimat majemuk (a) tersebut. Dengan demikian, terdapat dua kalimat tunggal yang digabung secara langsung dengan menggunakan konjungsi kesetaraan mempertentangkan pada kalimat majemuk contoh (a) di atas, yaitu:

a.1 Kemudian Marimar membayar kotak pensil pokemon itu setelah selesai menawar. a.2 Ia malah membayar kotak pensil pokemon itu dengan harga yang lebih mahal dari yang penjual sebutkan.

Kalimat (a.1) berstruktur sintaktis: S (Marimar) $+\mathrm{P}$ (membayar) $+\mathrm{O}$ (kotak pensil pokemon itu) $+\mathrm{K}$ (setelah selesai menawar), sedangkan kalimat (a.2) berstruktur sintaktis: $\mathrm{S}(\mathrm{Ia})+\mathrm{P}$ (malah membayar) + $\mathrm{O}$ (kotak pensil pokemon itu) $+\mathrm{K}$ (dengan harga yaang lebih mahal dari yang penjual sebutkan).

Hal yang sama terjadi pula pada penggunaan konjungsi kesetaraan yang bermakna 'penambahan, penjumlahan': dan, pada kalimat majemuk setara (b) di atas. Kalimat majemuk contoh (b) dibentuk dari dua kalimat tunggal:

b.1 Penjual kotak pensil hanya bisa bingung dengan kelakuan Marimar.

b.2 Penjual kotak pensil hanya bisa garuk-garuk kepala dengan kelakuan Marimar.

Kedua kalimat pembentuk kalimat majemuk (b) memiliki struktur sintaktis: S(penjual kotak pensil) $+\mathrm{P}$ (hanya bisa bingung) $+\mathrm{K}$ (dengan kelakuan Marimar) untuk kalimat (b.1) dan berstruktur sintaktis: $\mathrm{S}$ (penjual kotak pensil) $+\mathrm{P}$ (hanya bisa garuk-garuk kepala) $+\mathrm{K}$ (dengan kelakuan Marimar) untuk kalimat (b.2). Kedua contoh kalimat majemuk yang dibentuk dengan menggunakan dua konjungsi kesetaraan itu, siswa 020 telah memanfaatkan keberagaman struktur sintaktis (SPOK dan SPK) untuk menyampaikan gagasannya dalam teks anekdot yang diproduksinya.

Selanjutnya, dari tiga konjungsi kesetaraan yang tersedia sebagai piranti penghubung intrakalimat, tampaknya hanya dua jenis konjungsi itulah yang digunakan siswa. Siswa tidak menggunakan konjungsi kesetaraan yang berfungsi semantis: 'pilihan', yaitu konjungsi: atau.

Selain penggunaan dua konjungsi intrakalimat kesetaraan di atas juga pada teks yang diproduksi siswa 035 ditemukan kalimat yang menggunakan konjungsi kausalitas: karena, seperti pada contoh kalimat (c) di atas. Kalimat tersebut merupakan kalimat majemuk bertingkat karena terdiri dari induk kalimat dan anak kalimat. Untuk mengetahui induk kalimatnya, maka kalimat (c ) Marimar merenggut saat mendengar harga kotak pensil 
tersebut karena menurutnya harganya sangat mahal, harus dikembalikan pada pola dasar kalimat tersebut, yang berstruktur sintaktis $\mathrm{S}$ (Marimar) $+\mathrm{P}$ (merenggut) $+\mathrm{K}$ (saat mendengar harga kotak pensil tersebut) $\mathrm{K}$ (karena begitu). Pengisi fungsi keterangan sebab: karena begitu,pada pola dasar kalimat intinya diperluas menjadi kalimat baru yang berpola: $\mathrm{K}$ (menurutnya) $+\mathrm{S}$ (harganya) $+\mathrm{P}$ (sangat mahal). Kalimat yang terbentuklah hasil leluasa salah satu fungsi sintaktis pada sebuah kalimat tunggal menjadi kalimat baru sehingga tercipta kalimat majemuk bertingkat itulah yang disebut sebagai anak kalimat. Oleh karena itu: Induk kalimatnya adalah: (c.1). Marimar merenggut saat mendengar harga kotak pensil tersebut, dan anak kalimatnya adalah:

(C.2). Karena menurutnya harganya sangat mahal.

Patut ditambahkan bahwa dalam hal pemanfaatan konjungsi koordinatif/setara berupa pilihan penggunaan konjungsi intrakalimat, baik pada kalimat majemuk setara maupun bertingkat, siswa telah melakukan pilihan konjungsi: yang sesuai dengan fungsinya. Meskipun harus dicatat pula, konjungsi yang dipilih itu sangat terbatas jumlah.

Selanjutnya, deskripsi pilihan konjungsi koordinatif/setara dalam memproduksi untuk siswa percontoh berikutnya disajikan sebagai berikut.

Tabel 2 Deskripsi Penggunaan Konjungsi Koordinatif dalam Penyusunan Teks Anekdot SMK Muhammadiyah Mataram

\begin{tabular}{|l|l|l|}
\hline No. & Variabel & Deskripsi \\
\hline I. & Struktur Teks \\
\hline 1. & Judul & Cita-cita \\
\hline & $\begin{array}{l}\text { Suatu hari di sekolah, Adam ditegur } \\
\text { oleh guru karena sering datang } \\
\text { terlambat. } \\
\\
\text { Pak guru menyindir Adam tidak } \\
\text { memiliki jam di rumahnya sehingga dia } \\
\text { selalu datang terlambat. } \\
\text { Guru : "Adam kenapa kamu sering } \\
\text { terlambat, kalau kamu berangkat sekolah } \\
\text { saja tidak disiplin, sering terlambat, mau } \\
\text { jadi apa kamu nanti?" }\end{array}$ \\
\hline
\end{tabular}

\begin{tabular}{|l|l|l|}
\hline & \multicolumn{2}{|l|}{$\begin{array}{l}\text { Adam: "mau jadi anggota DPR pak". } \\
\text { Guru: Terdiam }\end{array}$} \\
\hline II. & Penggunaan Konjungsi \\
\hline & a. dan & - \\
\hline & b. atau & - \\
\hline & c. tetapi & - \\
\hline d. karena/sebab & $\begin{array}{l}\text { Suatu hari di sekolah, } \\
\text { Adam ditegur oleh } \\
\text { guru karena sering } \\
\text { datang terlambat. }\end{array}$ \\
\hline e. Sehingga & $\begin{array}{l}\text { Pak guru menyindir } \\
\text { Adam tidak memiliki } \\
\text { jam di rumahnya } \\
\text { sehingga dia selalu } \\
\text { datang terlambat }\end{array}$ \\
\hline
\end{tabular}

Tabel 2 di atas memperlihatkan siswa telah mengisi setiap struktur berpikir teks anekdot. Gagasan-gagasan pengisi struktur orientasi, krisis, dan reaksi dirajut dengan keterkaitan gagasan satu sama lain. Gagasan-gagasan dalam teks terpayungi oleh judul teks, "Cita-cita". Gagasan pertanyaan terlambat yang terekspresi melalui satuan-satuan verbal yang mengisi struktur teks membicarakan ihwal alasan kenapa seseorang dapat menjadi tidak disiplin. Siswa dalam memproduksi/mengonstruksi teks telah mempertimbangkan ciri teks sebagai sesuatu yang terkontrol, antara gagasan yang terdapat pada setiap struktur teks dengan judulnya diorientasikan pada gagasan yang sama.

Pilihan konjungsi koordinatif/setara berupa pemanfaatan konjungsi tidak ditemukan penggunaan konjungsi kesetaraan: dan, atau dan tetapi. Termasuk dalam hal ini, juga ditemukan penggunaan konjungsi kebertingkatan: karena. Selanjutnya, untuk pilihan konjungsi koordinatif/setara berupa penggunaan konjungsi antarkalimat atau antarparagraf hanya dijumpai penggunaan konjungsi: sehingga yang menghubungkan struktur krisis dan reaksi. Untuk penggunaan piranti kebahasaan kata dan kalimat teks anekdot, siswa hanya tidak menggunakan kata kerja material dan kalimat perintah. Untuk lebih jelasnya dapat terlihat dalam kalimat berikut: 
a. Suatu hari di sekolah, Adam ditegur oleh guru karena sering datang terlambat.

b. Pak guru menyindir Adam tidak memiliki jam di rumahnya sehingga dia selalu datang terlambat.

Struktur sintaksis kalimat (a) K (suatu hari di sekolah) $+\mathrm{S}$ (Adam) $+\mathrm{P}$ (ditegur) $+\mathrm{O}$ (oleh pak Guru) + K (karena sering datang terlambat). Kalimat tersebut termasuk kalimat pasif. Adapun kalimat (b) penggunaan konjungsi dalam dua kalimat tunggal menjadi kalimat majemuk dengan bentuk kalimat:

b.1 Pak guru menyindir Adam tidak memiliki jam di rumahnya

b.2 Dia selalu datang terlambat

Dua kalimat di atas memiliki struktur: $\mathrm{S}$ (Pak guru $)+\mathrm{P}$ (menyindir $)+\mathrm{O}$ (Adam) $+\mathrm{K}$ (tidak memiliki jam di rumahnya) dan $\mathrm{S}$ (dia) + $\mathrm{P}$ (selalu datang) $+\mathrm{K}$ (terlambat). Polanya (SPOK) dan (SPK). Kedua kalimat tunggal itu digabungkan dengan konjungsi sehingga dan membentuk kalimat majemuk menyatakan sebab dan akibat. Patut ditambahkan bahwa dalam hal pemanfaatan konjungsi koordinatif/setara berupa pilihan penggunaan konjungsi intrakalimat, baik pada kalimat majemuk setara maupun bertingkat, siswa 055 telah melakukan pilihan konjungsi: yang sesuai dengan fungsinya. Meskipun harus dicatat pula, konjungsi yang dipilih itu sangat terbatas jumlah.

Tabel 3 Sebaran Penggunaan Konjungsi Koordinatif dalam Penyusunan Teks Anekdot Berdasarkan Sekolah Sampel

\begin{tabular}{|l|l|l|c|}
\hline & & \multicolumn{2}{|c|}{ Skor } \\
\cline { 3 - 4 } No. & $\begin{array}{c}\text { Komponen/ } \\
\text { Variabel }\end{array}$ & $\begin{array}{c}\text { SMAN 1 } \\
\text { Mataram }\end{array}$ & $\begin{array}{c}\text { SMK } \\
\text { Muhammadiyah }\end{array}$ \\
\hline I. & Struktur Teks \\
\hline 2. & Orientasi & $20=20$ & $20=20$ \\
\hline 3. & Krisis & $20=20$ & $20=20$ \\
\hline 4. & Reaksi & $20=20$ & $20=20$ \\
\hline II. & Penggunaan Konjungsi Koordinatif \\
\hline & a. dan & $24=20$ & $29=17$ \\
\hline & b. atau & $0=20$ & $1=1$ \\
\hline & c. tetapi & $2=20$ & $3=3$ \\
\hline
\end{tabular}

Tabel 3 di atas menggambarkan jumlah penggunaan siswa dalam mengisi struktur dan konjungsi koordinatif. Kedua sekolah sampel telah mengisi struktur teks, selanjutnya dapat dilihat penggunaan konjungsi koordinatif pada kedua sekolah. Penggunaan konjungsi 'dan' pada SMAN 1 Mataram sebanyak 24 kali. sedangkan SMK Muhammadiyah dari 20 siswa hanya 17 siswa yang menggunakan dengan jumlah kemunculan 29 kali. Hal ini bisa saja terjadi, misalnya dalam satu teks terdapat dua atau bahkan 3 konjungsi 'dan'. Penggunaan konjungsi 'atau' tidak digunakan siswa SMAN 1 Mataram dalam memproduksi teks, sedangkan pada SMK Muhammadiyah ditemukan satu siswa yang menggunakan konjungsi tersebut. Penggunaan konjungsi 'tetapi' tidak jauh berbeda dari konjungsi 'atau'. Dari 20 siswa di SMAN 1 Mataram hanya dua siswa yang menggunakan konjungsi 'tetapi' dan tiga siswa pada SMK Muhammadiyah Mataram.

Tidak cukup hanya menggambarkan jumlah penggunaan konjungsi koordinatif, selanjutnya untuk membuktikan kemampuan siswa, jumlah tersebut diakumulasikan ke dalam skor berikut.

Tabel 4 Skor Penggunaan Konjungsi Koordinatif dalam Penyusunan Teks Anekdot Berdasarkan Sekolah Sampel

\begin{tabular}{|l|l|c|c|}
\hline \multirow{2}{*}{ No } & \multirow{2}{*}{$\begin{array}{c}\text { Komponen/ } \\
\text { Variabel }\end{array}$} & $\begin{array}{c}\text { SMAN 1 } \\
\text { Mataram }\end{array}$ & $\begin{array}{c}\text { SMK } \\
\text { Muhammadiyah }\end{array}$ \\
\cline { 3 - 4 } & & 3 & 3 \\
\hline I. & Struktur Teks \\
\hline 1. & Orientasi & 3 & 3 \\
\hline 2. & Krisis & 3 & 3 \\
\hline 3. & Reaksi & $9 / 3 \times 10=30$ & $9 / 3 \times 10=30$ \\
\hline & Skor & 2 & 1,7 \\
\hline II. & Penggunaan Konjungsi Koordinatif \\
\hline & a. dan & 0 & 0,1 \\
\hline & b. atau & 0,2 & 0,2 \\
\hline & c. tetapi & $2,2 / 3 \times 10=7,3$ & $2 / 3 \times 10=6,6$ \\
\hline & Skor & 37 & 37 \\
\hline & Total Skor & \multicolumn{2}{|c|}{37} \\
\cline { 2 - 4 } & $\begin{array}{c}\text { Skor } \\
\text { Keseluruhan }\end{array}$ & \multicolumn{2}{|c|}{} \\
\hline
\end{tabular}

Keterangan: skor diperoleh dengan cara membagi jumlah siswa yang menggunakan konjungsi koordinatif dengan jumlah siswa dikalikan bobot skor. Contoh 20/20x2=2 .

Tabel 4 di atas, menggambarkan bobot skor tertinggi dari struktur berpikir adalah 3 . Skor tersebut diperoleh dari menjumlahkan tiga aspek struktur berpikir orientasi, krisis, dan 
reaksi. Data di atas dapat memperlihatkan bahwa seluruh siswa telah mampu mengisi struktur teks anekdot. Bobot skor tertinggi konjungsi koordinatif/setara adalah 2 dengan menjumlahkan keseluruhan aspek konjungsi 'dan', 'atau', dan 'tetapi'. Meskipun dalam teks anekdot terdapat konjungsi bertingkat, tetapi penelitian ini hanya untuk menggambarkan hasil pemanfaatan siswa dalam penggunaan konjungsi koordinatif/setara.

Selanjutnya dapat dilihat, kemampuan SMAN 1 Mataram dalam penggunaan konjungsi koordinatif 'dan' lebih tinggi dari SMK Muhammadiyah dengan skor 2. Kemudian penggunaan konjungsi 'atau' hanya terdapat pada SMK Muhammadiyah dengan skor 0,1. Selanjutnya, penggunaan konjungsi 'tetapi' SMK Muhammadiyah lebih tinggi dengan skor 0,3 .

Hal ini dapat membuktikan bahwa penggunaan konjungsi koordinatif masih monoton pada penggunaan 'dan', siswa masih kesulitan dalam menggunakan konjungsi 'atau' dan 'tetapi'. Tetapi jika dilihat dari tabel 4 di atas penggunaan siswa memanfaatkan konjungsi koordinatif di sekolah swasta sedikit lebih variatif dari sekolah negeri dengan lebih tingginya penggunaan 'atau' dan 'tetapi' .

Kemampuan siswa dalam memproduksi teks anekdot masih dalam kategori kurang dalam pemanfaatan konjungsi koordinatif/setara khususnya dalam sintaksis. Siswa menggunakan semua aspek struktur isi tetapi pemanfaatan konjungsi koordinatif/setara dalam penggunaan piranti kebahasaan masih kurang. Hal ini dapat dijelaskan berdasarkan skor SMAN 1 Mataram 37 dan skor SMK Muhammadiyah 37 dengan total keseluruhan skor 37.

Penelitian ini tidak hanya mendeskripsikan kemampuan siswa dalam memanfaatkan konjungsi koordinatif/setara tetapi bertujuan untuk melihat sejauh mana kemampuan siswa di dalam memproduksi teks anekdot telah terlaksana melalui daring atau belajar online. Berdasarkan hasil penelitian, pembelajaran memproduksi teks anekdot tidak berjalan sesuai yang diharapkan. Siswa lebih banyak memanfaatkan konjungsi 'dan' dan sedikit sekali yang memanfaatkan konjungsi koordinatif/setara lainnya. Pembelajaran daring membuktikan bahwa siswa menjadi kurang mampu mengekspresikan hasil tulisannya, karena terpatok pada internet dan tidak berani mencoba memulai dengan kemampuannya sendiri. Berdasarkan hal tersebut dapat disimpulkan bahwa penelitian di SMAN 1 Mataram dan SMK Muhammadiyah Mataram berjalan baik, tetapi hasil kemampuan siswa berada dalam kategori kurang.

Berdasarkan penjelasan di atas, penelitian ini diharapkan dapat menjadi tolok ukur dalam penelitian selanjutnya, khususnya dalam penelitian pembelajaran daring. Peneliti dapat menentukan langkah selanjutnya dalam membantu siswa dalam meningkatkan kemampuan menulis khususnya langkah dalam memperkaya daya ungkap pemanfaatan konjungsi koordinatif/setara dalam memproduksi teks.

\section{KESIMPULAN}

Penelitian ini bertujuan untuk melihat sejauh mana kemampuan siswa dalam memproduksi teks dengan memanfaatkan konjungsi koordinatif/setara. Berdasarkan penelitian yang telah dilakukan kemampuan siswa dalam penggunaan konjungsi koordinatif dalam memproduksi teks anekdot berada dalam kategori kurang. Setelah menganalisis hasil kerja siswa SMAN 1 Mataram dan SMK Muhammadiyah di Kota Mataram, Siswa dominan hanya menggunakan konjungsi koordinat 'dan', hanya sedikit siswa yang menggunakan 'atau' dan 'tetapi'. Bahkan karena penggunaan daring, beberapa siswa masih menggunakan contoh yang mereka temukan di internet, banyak siswa yang tidak berani mencoba membuat teksnya sendiri.

Masih perlu adanya kesadaran dari setiap pendidik untuk membantu siswa dalam menemukan langkah dalam menyiasati penggunaan konjungsi koordinatif dalam memproduksi teks. Keberhasilan pembelajaran tidak dapat terbentuk tanpa dukungan internal dan eksternal.

Hasil dari penelitian ini menunjukkan bahwa siswa telah mampu memproduksi teks dengan memanfaatkan konjungsi koordinatif 'dan' tetapi untuk memanfaatkan konjungsi 
koordinatif 'atau', dan 'tetapi', masih relatif kurang.

\section{DAFTAR PUSTAKA}

Alwi, hasan, dkk. 2003. Tata Bahasa Baku Bahasa Indonesia. Jakarta: Balai Pustaka.

Chaer, Abdul. 2009. Sintaksis Bahasa Indonesia. Jakarta: Rineka Cipta.

Darma, Yoce Aliah. 2009. Analisis Wacana Kritis. Bandung: YRAMA WIDYA

Emzir \& Saifur, Rohman. 2016. Teori dan Pengajaran Sastra. Jakarta: PT Raja Grafindo Persada

Irwansyah.2018. Analisis Kemampuan Siswa Kelas X MAN 1 Bima dalam Memproduksi Teks Anekdot dengan Pendekatan Saintifik. Tesis: Universitas Mataram

Kosasih, E. 2014.Jenis-Jenis Teks Analisis Fungsi, Struktur, dan Kaidah serta Langkah Penulisannya dalam Mata Pelajaran Bahasa Indonesia SMA/MA/SMK. Bandung:Yrama Wiidya

Mahsun. 2017. Metode Penelitian Bahasa: Tahapan, Strategi, Metode, dan Tekniknya. Depok: PT. Raja Grafindo Persada.

Moleong, J. Lexi. 2012. Metodelogi Penelitian Kualitatif (edisi revisi). Bandung: PT REMAJA ROSDAKARYA

Pinanka, Theresia .2016. Analisis Teks dan Konteks pada Wacana Anekdot Siswa Kelas X SMA Negeri 1 Surakarta. Tesis. Surakarta: Universitas Sebelas Maret.

Santosa, Riyadi. 2011. Logika Wacana: Analisis Hubungan Konjungsi dengan pendekatan Linguistik Sistemik Fungsional. Surakarta: LPP UNS dan UNS Press.

Simanungkalit, Kaleb E.2017. Peningkatan Motivasi dan Keterampilan Menulis Teks Anekdot dengan Model Problem Based Learning (PBL) dan Penggunaan Media Gambar Karikatur di Kelas X MM 3 SMK Negeri 1 Gondang. Tesis. Surakarta: Universitas Sebelas Maret.
Sugiyono. 2016. Metode Penelitian Pendidikan Pendekatan Kualitatif, kuantitatif dan $R \& D$. Bandung: Alfabeta

Wiratno, Tri. 2014. Jenis-jenis Teks (Peningkatan Kompetensi terhadap Kurikulum 2013 bagi Tenaga Teknis Badan Bahasa dan Dosen Bahasa dan Sastra Indonesia). Jakarta: Badan Bahasa.

Zainurrahman. 2011. Menulis dari Teori Hingga Praktik (Penawar Racun Plagiarisme). Bandung: Alfabet. 